\title{
Treatment effectiveness evaluation of dental caries as a factor affecting patients' quality of life
}

\author{
${ }^{1}$ Mikhail Postnikov, ${ }^{1}$ Svetlana Chigarina, ${ }^{1}$ Ksenia Gaylis, ${ }^{2}$ Svetlana Plamadeala, \\ ${ }^{3}$ Elizaveta Postnikova, ${ }^{\star 2}$ Cristina Postaru \\ ${ }^{1}$ Therapeutical Dental Department, State University of Medicine, Samara, Russian Federation \\ ${ }^{2}$ Ion Lupan Pediatric Surgery and Pedodontic Department, Nicolae Testemitanu State University of Medicine and Pharmacy \\ Chisinau, the Republic of Moldova \\ ${ }^{3}$ Undegraduate Student, Sechenov 1st State University of Medicine, Moscow, Russian Federation
}

Authors' ORCID iDs, academic degrees and contributions are available at the end of the article

*Corresponding author - Cristina Postaru, e-mail: cristina.postaru@usmf.md

Manuscript received July 05, 2021; revised manuscript August 18, 2021; published online September 10, 2021

\begin{abstract}
Background: The study of the patient's quality of life is an important condition for assessing the effectiveness of the treatment and the clinical condition of patients after treatment, in addition to objective diagnostic methods. The purpose of the study was to investigate the dynamics of changes in the quality of life of dental patients suffering from caries of the contact areas of the lateral group of teeth, after treatment in accordance with the established plan for the use of various matrix systems, in the study groups.

Material and methods: The study involved 147 patients: 48 patients of the 1st experimental group; 54 patients of the 2nd experimental group; 45 patients of the 3rd experimental group.

Results: In the course of the study, it turned out that such a criterion as the quality of life is an informative dynamic indicator, the value of which depends on the method of treatment used.

Conclusions: In the course of the study, the effectiveness of the use of a separation-retaining device for the restoration of the lateral group of teeth during the treatment of caries in the contact areas of the teeth was assessed as a factor influencing the quality of life of patients.

Key words: dental caries, quality of life of the patient, treatment.
\end{abstract}

\section{Cite this article}

Postnikov M, Chigarina S, Gaylis K, Plamadeala S, Postnikova E, Postaru C. Treatment effectiveness evaluation of dental caries as a factor affecting patients' quality of life. Mold Med J. 2021;62(3):36-39. https://doi.org/10.52418/moldovan-med-j.64-3.21.07.

\section{Introduction}

Determination of the quality of life of dental patients, as a set of factors that determine the physical, psychological, emotional, social state of the patient based on his subjective perception, serves as a sufficient basis for the characteristics of the treatment. When considering the issue of not only the quality of care provided to the patient, but also the long-term results of the therapy, they take into account the general negative impact on the physiological parameters and the most important functions of the patient - his physical, psychological, emotional and social state [1]. Thus, the purpose of this study was to investigate the quality of life of patients during treatment.

The ability to obtain accurate information about the indicators of the quality of life of a patient, a group of patients, allows one to give a reliable assessment of the quality of life of society in its various sections in dynamics, determining the effectiveness of numerous reforms and programs aimed at increasing the level of well-being and improving the quality of life of the population [2].
Therefore, to assess the severity of the disease and the effectiveness of treatment, only objective clinical criteria and laboratory and instrumental data are not enough, since their interpretation is based on the subjective perception of a specialist and his idea of health. The methodological reasonableness of the quality of life provides the possibility of integrating this parameter into the system for evaluating the effectiveness of treatment methods, which increases the reliability of assessing the patient's condition. Such a medical approach meets the most important principle of the clinical work of a doctor - "treat the patient, not the disease" [2].

The questionnaires of the quality of life, to the greatest extent, allowing getting a holistic idea of the patient's wellbeing, remain the main tools for assessing the "holistic situation of the disease through the eyes of the patient". The main method for assessing the quality of life is the use of standardized questionnaires. In addition to questionnaires for determining the general medical condition of a patient, there are highly specialized options, such as the "Oral Health Impact Profile" OHIP14 [3-4]. With the localization of the carious process on the contact areas of the lateral 
group of teeth, a patient suffers comparable to other severe chronic dental diseases, such as periodontitis, diseases of the oral mucosa [5]. Patients experience embarrassment about the appearance of their mouth, irritation about their appearance, a feeling of self-doubt during a conversation, eating. Patients are most concerned about the reaction of the causative teeth to temperature stimuli and the feeling of bad breath, which indicates their physical suffering [1]. Suspiciousness, anxiety, emotional instability, irritability are manifested in patients with dental caries, which negatively affect the quality of life [2]. It is noticed that the decrease in the quality of life indicators depends on the duration of the course of dental caries, untimely referral to specialists and the clinical severity of the process.

The ability to obtain accurate information about the indicators of a person's quality of life allows one to give a reliable assessment of the patient's condition in dynamics, determining the effectiveness of the therapy. The concept of "quality of life" is the basis of a new paradigm for understanding the disease and determining the effectiveness of treatment methods [4].

\section{Material and methods}

During the research, the aim was to evaluate the effectiveness of the use of various matrix systems for the restoration of the lateral group of teeth during the treatment of caries in the contact areas of the teeth, as a factor affecting the quality of life of patients [6]. A total of 147 patients were involved: 48 of them were included in the 1st group, who were treated by restoration technique using a retaining ring, a sectional matrix and a wedge; 54 patients of the 2 nd group, who had a fixation system made of nickel-titanium (Ni-Ti) alloy with an adaptive working surface, instead of a fixing ring; the remaining 45 patients of the 3 rd group received a separation-holding device for the restoration of the lateral group of teeth [7]. Patients of all groups received treatment in accordance with clinical guidelines (treatment protocols) for the diagnosis of dental caries approved by Resolution No 18 of the Council of the "Dental Association of the Russian Federation" dated September 30, 2014 - anesthesia, initiation of the tooth surface for treatment (removal of supra and subgingival teeth deposits), preparation of hard tooth tissues, removal of affected dentin, installation of the matrix system and wedges, etching and bonding the dental cavity, layer-by-layer restoration of the surface of missing tissues, removal of auxiliary devices, grinding, polishing, occlusal checking $[5,8,9]$. When presenting the results of evaluating interventions, the indicators recommended by the editors of the journals Evidence-Based Medicine, ACP Journal Club, adopted in evidence-based medicine were calculated [10]. The statistical significance of differences for testing the hypothesis about the relationship of two qualitative characteristics in the groups of subjects was calculated by the methods of nonparametric statistics using the $\chi^{2}$-square test with Yates' correction or Fisher's test (if the numbers in the cells of the $2 \times 2$ contingency table are less than 5 ). The sample parameters given in the tables have the following meaning: $\mathrm{M}$ - mean, s - standard (root-mean-square) deviation, $\mathrm{m}$ - mean error, $\mathrm{n}$ - volume of the analyzed subgroup, $\mathrm{p}$ - achieved level of significance. The critical value of the significance level was taken equal to $5 \%$. Data analysis was carried out using the SAS 8 and SPSS 11 software packages. To identify the dependence of the treatment on the psychoemotional and physical state of patients in dynamics, a survey was conducted using a specialized validated questionnaire of quality of life "Profile of the impact of dental health" OHIP-14 RU, which contains 14 questions reflecting the impact of the patient's dental status on everyday life. The choice of this questionnaire was carried out in accordance with the requirements of International Association for the Assessment of Quality of Life (IQOLA) and Good Clinical Practice (GCP), and was mediated by a specific clinical situation. Five options were offered from "very often" to "never" and are rated from 5 to 1 points, respectively. Further, the points were summed up, and according to the result obtained, the level of quality of life of patients was determined, where 14-28 is a good level of quality of life, 29-56 is satisfactory, 57-70 - unsatisfactory quality of life.

\section{Results and discussion}

Patients were questioned before treatment, then after $1,3,6$ and 18 months. As a result of the survey, were received 5 indicators of quality of life for each of 147 patients. Thus, an array of data from 735 questionnaires was formed. Statistical processing of the information obtained made it possible to calculate the average indicators for the quality of life index in each clinical group. Changes in the indicators of the quality of life index over time for each of the groups of patients with dental caries of the contact surfaces of the lateral group of teeth are reflected in table 1 . The value of statistical significance according to the calculations showed the same value of $\mathrm{p}>0.05$ for all groups and terms of the study.

Dynamics of quality of life indicators, the difference in indicators before and after treatment in patients with the use of a separation-holding device for the restoration of the lateral group of teeth (group I), a fixation system made of nickel-titanium alloy with an adaptive working surface (group II) compared with patients in the group (III) and restoration using a retaining ring - provides a visual display of the effectiveness of using modern matrix systems in the treatment of dental caries, not only for a satisfactory clinical result, but also to improve the general condition of patients.

According to the results of the study, it was found that the level of quality of life in the studied groups during the treatment had a unidirectional tendency to improve 1 month after the treatment (fig. 1). However, the results in the 1st clinical group differed markedly from the other 2 groups, which almost identically achieved the level of "good" quality of life in patients. Subsequently, was observed a rapid decline in the quality of life in the first group and a gradual discrepancy between the data in the second and third groups according to the results of the questionnaire after 3 months. According to the results of the survey of patients 6 months after treatment, data were obtained indicating changes in 
Table 1. Indicators of the quality of life index of patients during the study

\begin{tabular}{|c|c|c|c|c|c|c|}
\hline \multirow[b]{3}{*}{ Groups } & \multicolumn{6}{|c|}{ Indicators $(\mathrm{M} \pm \mathrm{m})$} \\
\hline & \multicolumn{6}{|c|}{ OHIP 14} \\
\hline & $\begin{array}{c}\text { Before treat- } \\
\text { ment }\end{array}$ & 1 month later & $\begin{array}{l}3 \text { months } \\
\text { later }\end{array}$ & $\begin{array}{l}6 \text { months } \\
\text { later }\end{array}$ & $\begin{array}{l}18 \text { months } \\
\text { later }\end{array}$ & $\begin{array}{c}\text { Differences between } \\
\text { indicator before and } \\
\text { after treatment }\end{array}$ \\
\hline Group I (n=48) & $63.29 \pm 0.62$ & $35.98 \pm 0.37$ & $46.46 \pm 0.24$ & $61.72 \pm 0.16$ & $69.71 \pm 0.14$ & $-6.42 \pm 0.52$ \\
\hline Group II (n=54) & $62.7 \pm 0.59$ & $16.07 \pm 0.35$ & $18.92 \pm 0.25$ & $30.08 \pm 0.16$ & $37.12 \pm 0.15$ & $25.58 \pm 0.34$ \\
\hline Group III $(n=45)$ & $63.39 \pm 0.80$ & $16.21 \pm 0.46$ & $17.79 \pm 0.31$ & $19.79 \pm 0.18$ & $20.77 \pm 0.19$ & $42.62 \pm 0.61$ \\
\hline
\end{tabular}

the quality of life of patients of the 1st group to values "unsatisfactory", which practically corresponded to the figures "before treatment". In the 2nd group, the indicators were the boundary data of "good" and "satisfactory" quality of life. The best result, according to the study of the quality of life, was formed in the third study group. The indicators in the third group revealed a "good" level of quality of life of dental patients. The situation after the examination of patients 18 months after the treatment carried out also confirms the tendency formed in each of the clinical groups towards the dynamic development of the state of the quality of life.

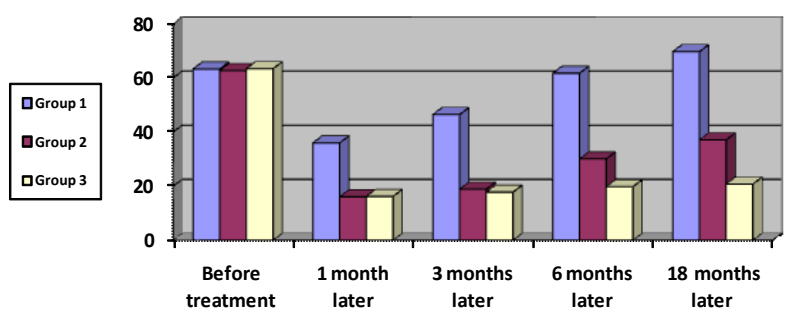

Fig. 1. Dynamics of changes in the quality of life of dental patients of various clinical groups

\section{Conclusions}

Thus, in the process of studying the results of the questionnaire survey of patients before and after the treatment, the dependence of the level of quality of life depending on the treatment performed was shown. The use of the retaining ring in the 1st group was found to be untenable, since it allowed achieving a "satisfactory" result only a month after the treatment, after which the indicator began to worsen rapidly. The use of a fixation system made of nickel-titanium (NI-TI) alloy with an adaptive working surface has finally allowed achieving a "satisfactory" result due to the modern technology. At the same time, having disadvantages in the form of the need for additional tools for work, the doctor was forced to carry out additional manipulations during the treatment process, which, most likely, influenced the manifestations of negative results in the form of complications that affected the quality of life of patients of the 2nd group. As noted, in the group with the use of a separation-holding device for the restoration of the lateral group of teeth of our design, the level of quality of life was as stable as possible and was within the "good" grade. This state of patients in the 3rd group proves the effectiveness of the tool that was developed in terms of the level of treatment provided in the long-term period.

\section{References}

1. Gil'miiarov EM, Arnautov BP, inventors. Separatsionno-uderzhivaiushchee ustroistvo dlia restavratsii bokovoi gruppy zubov [Separation and retaining device for the restoration of the lateral group of teeth]. The Russian Federation №153071. 2015 Jun 5. Russian.

2. Baker F, Intagliata J. Quality of life in the evaluation of community support systems. Eval Program Plann. 1982;5(1):69-79. doi: 10.1016/01497189(82)90059-3.

3. Straus ShE, Richardson VS, Glatseio P, Heins BR. Meditsina, osnovannaia na dokazatel'stvakh [Evidence-based medicine]. Moscow: GEOTARMedia; 2010. 322 p. Translation from English by Vlasov VV. Russian.

4. Shpigel' AS, Belousova LG, Haikin MB. Printsipy dokazatel'noi meditsiny kak metodologicheskaia osnova priniatiia klinicheskikh i upravlencheskikh reshenii v stomatologii [Principles of evidence-based medicine as a methodological basis for the adoption of clinical and managerial decisions in dentistry]. Izvestiia Samarskogo Nauchnogo Tsentra Rossiiskoi Akademii Nauk [Bull Samara Sci Cent Russian Acad Sci]. 2015;17(1-3):778-780. Russian.

5. Dubova MA, Salova AV, Hiora ZhP. Rasshirenie vozmozhnostei esteticheskoi restavratsii zubov. Nanokompozity [Expanding the possibilities of aesthetic dental restoration. Nanocomposites]. Sankt Petersburg; 2005. 144 p. Russian.

6. Novik AA, Ionova TI. Rukovodstvo po issledovaniiu kachestva zhizni v meditsine [Guidelines for research on quality of life in medicine]. 2nd ed. Moscow; 2007. 320 p. Russian.

7. Gazhva SI, Guluev RS, Gazhva IuV. Kachestvo zhizni patsientov s zabolevaniiami polosti rta (obzor literatury) [The quality of life in paitents with diseases of oral cavity (review of literature)]. Sovremennye Problemy Nauki i Obrazovaniia [Mod Probl Sci Educ]. 2012;(4):25-27. Russian.

8. Gil'miiarov EM. Monoportsionnaia tekhnika v posteriornoi restavratsii zubov [Monoportioning technique in posterior dental restorations]. Dental magazine. 2013;(9/117):84-86. Russian.

9. Kotelnikov GP, Shpigel' AS. Sistema vnedreniia printsipov dokazatel'noi meditsiny - neobkhodimyi i obiazatel'nyi komponent povysheniia kachestva obrazovaniia $\mathrm{v}$ usloviiakh modernizatsii zdravookhraneniia [System of introduction and realization of principles of evidence-based medicine as a necessary and mandatory element of improvement of quality of education in the context of health care modernization] Meditsinskoe Obrazovanie i Professional'noe Razvitie [Med Educ Prof Dev]. 2012;(1):43-50. Russian.

10. Lobovkina LA, Romanov AM. Algoritm esteticheskoi restavratsii perednikh i bokovykh zubov [Algorithm for aesthetic restoration of anterior and lateral teeth]. Moscow: Medpress-Inform; 2008. 47 p. Russian. 


\section{Authors' ORCID iDs and academic degrees}

Mikhail Postnikov, MD, PhD, Professor of Dental Medicine - https://orcid.org/0000-0002-2232-8870

Svetlana Chigarina, MD, PhD, Associate Professor of Dental Medicine - https://orcid.org/0000-0002-7008-5981

Ksenia Gaylis, MD, PhD Student - https://orcid.org/0000-0003-3137-2045

Svetlana Plamadeala, MD, PhD Applicant - https://orcid.org/0000-0003-0635-1525

Elizaveta Postnikova, MD, Undergraduate Student - https://orcid.org/0000-0002-5989-1704

Cristina Postaru, MD, PhD Candidate - https://orcid.org/0000-0002-7101-6443

\section{Authors' contributions}

MP conceptualized the idea and revised critically the manuscript, SC completed the final text, KG wrote the first manuscript, SP collected data, EP conducted literature review, CP revised the final text. All the authors approved the final version of the manuscript.

\section{Funding}

This study was supported by Nicolae Testemitanu State University of Medicine and Pharmacy, Chisinau, the Republic of Moldova and State University of Medicine, Samara, the Russian Federation. The review study was the authors' initiative. The authors are independent and take responsibility for the integrity of the data and accuracy of the data analysis.

\section{Ethics approval and consent to participate}

The study was approved by the Research Ethics Committee of Dental Association of the Russian Federation (Resolution No 18 of 30.0.2014). An informed consent from all participants in the study was obtained.

\section{Conflict of Interests}

The authors have no conflict of interests to declare. 